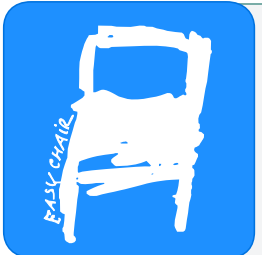

EPiC Series in Biological Sciences

Volume 1, 2021, Pages 33-40

Proceedings of KOBI 2nd International Confer-

ence on Management of Tropical Biodiversity for

Human Welfare: From Ecosystem to Molecular

\title{
Joyful Learning Model: Improving Higher Order Thinking Skill and Students' Learning Motivation at Senior High School
}

\author{
Siti Ardiyanti ${ }^{1 *}$, Mahwar Qurbaniah ${ }^{1}$, Nuri Dewi Muldayanti ${ }^{1}$ \\ ${ }^{1}$ Universitas Muhammadiyah Pontianak, Indonesia \\ sitiardiyanti.ipalegmail.com
}

\begin{abstract}
Higher-Order Thinking Skills (HOTS) is one of the most important aspects to increase the quality of education. However, HOTS in SMA Muhammadiyah 1 Pontianak is considered still not appearing. This can be seen from the practice questions given by the teacher still using the verb C1-C3. Besides that based on the result of interviews with students, the learning pattern applied by biology teachers who still conventional method makes students bored and less motivated to study biology. The use of a joyful learning model is expected to help students to improve their HOTS and motivation in learning. This study aimed to determine the effect of a joyful learning model on students' HOTS and their learning motivation. This quasi-experimental research involved 30 students of X MIA 1 and X MIA 2 as the sample. Data were collected through test and questionnaires which was analyzed using effect size. The results obtained from the test show that joyful learning model could improvements in the both students' HOTS and learning motivation, indicated by the value of effect size HOTS obtained at 0,31 which is included in the medium category, and students' motivation in learning with the effect size value at 1,15 which is categorized as very high. Thus, joyful learning could improve HOTS and learning motivation in senior high school.
\end{abstract}

\section{Introduction}

Qualified human resources can only be realized with a quality education. Quality education is an education that can develop positive potentialities latent in students. With this quality education, creating potential young workers are resilient and ready to compete in the global community. Therefore, improving the quality of education is not negotiable to improve the quality of the nation's resources in Indonesia (Widodo, 2015), especially in the learning process in the field of Biology. 
In general, Higher-Order Thinking Skills (HOTS) of the Indonesian students' are lower compared to other countries. It was proven by the Program for International Students Assessment (PISA) and Trend in the International Mathematics and Science Study (TIMSS) report which stated that Indonesian students were only able to achieve the second level of the six-thinking level in the competed for questions. This report indicated the low ability of students in logical and rational thinking (Kayali \& Yilmaz, 2016). This condition led to Indonesia's achievement ranking at a lower level compared to other participating countries (Sharma, 2013).

High order thinking skill is one of the important aspects that play a role in improving the quality of education. According to (Yee, 2015) high order thinking skills (HOTS), can create an individual able to interpret, analyze, or manipulate the information obtained. The high order thinking skill make students can distinguish ideas or ideas clearly, be able to solve problems, argue well, be able to hypothesize, and understand complex things become clearer (Widodo \& Kawarwati, 2013).

Based on the results of interviews conducted with the X grade Biology teacher MIA in SMA Muhammadiyah 1 Pontianak, the High Order Thinking Skill in students of SMA Muhammadiyah 1 Pontianak is still considered not appearing. It can be seen from the questions given by the teacher. The questions have given still use verbs $\mathrm{C} 1$ to $\mathrm{C} 3$. If given questions with verbs $\mathrm{C} 4$ and above, students will be confused. According to (Rochman \& Hartoyo, 2018). The habit of taught low order thinking to the student caused hasn't thought of high order thinking skills (HOTS). HOTS supposedly required for solving problems in a creative and innovative. To overcome this problem, senior high school students should be directed to develop HOTS.

Other issues such as that based on interviews with students of class X MIA 1 and 2 patterns applied to learn in the subject of biology, teachers still use conventional methods so that students are less motivated to follow the teaching of Biology well. Equally with the statement of Slameto (2013) which states teachers who used to teach with conventional methods of lecture or course, make students bored, sleepy, passive, and just record it. As a result, students are lazy to learn and lack the motivation to learn.

According to (Nashar, 2004) students' learning motivation in each learning activity plays an important role to improve student achievement in certain subjects. According to Ulya, Irawati, \& Maulana (2016), low student motivation can have an impact on the student learning process and results are not inflated properly, even greatly decreased. This is equally with the results (Hamdu \& Agustina, 2011) which state that the higher the students' motivation, make the higher the learning achievements obtained. Thus, one alternative learning model is expected to tackle this all by creating fun learning conditions by applying the joyful learning model.

Joyful Learning is a learning process or learning experience that makes students feel pleasure in the learning scenario or learning process. Joyful learning can help develop thinking skills, build their concept of the subject matter and the ability to formulate conclusions on students and exposes students to favorable circumstances to make the students like material provided for the learning process designed to be more dynamic, stressing - visual stuff, and fun, which is expected to increase students' high-order thinking skills. Based on research (Permatasari, Mulyani, \& Nurhayati, 2014), it is known that joyful learning has a big impact on student achievement, student achievement will be increased using joyful learning.

\section{Materials and Methods}

This research was conducted in two classes, namely the experimental class which was treated using the joyful learning model and the control class using the conventional learning model to determine the most effective learning models to improve HOTS and learning motivation. This

research was conducted from January to February 2019. The research method used in this study is a 
quasi-experimental design method. The research design used by the authors in this study is a nonequivalent control group design (Sugiyono, 2015).

In this study, the pre-test was given to the experiment class and control class. Then, the post-test as practiced to the experiment students after they learn about Fungi using a joyful learning model, meanwhile the control class was given the conventional learning model. The population of this research was all ten (X) grade students of SMA Muhammadiyah 1 Pontianak in the academic year 2018/2019. The sampling technique was random sampling, as the homogeneity tests result in the average score of students' protista daily test is homogeneous. The X MIA 2 class was selected as the experiment class and X MIA 1 class as the control. The primary variable of this study is the independent and dependent variables. The independent variable is the joyful learning model. The dependent variable in this study is high order thinking skills and learning motivation.

Data collection techniques used in this study are in the form of measurements made to determine students' high order thinking skills through the provision of pretest and posttest questions by using two-tier multiple-choice questions as many 6 questions. As well as indirect communication techniques that are carried out to determine student learning motivation through the provision of student learning motivation questionnaire sheets. The questionnaire was made with a Likert scale in the form of a checklist containing questions with closed answers about student learning motivation. According to (Widiawati, Subandi, \& Fajaroh, 2015) there are four indicators of learning motivation, namely indicators of student attention, indicators of confidence, indicators of willingness to learn, and indicators of cooperation.

Data obtained from the results of the study were then analyzed to determine differences in HOTS and student learning motivation between the two learning classes. the difference in high order thinking skills of students tested with effect size. Effect size can be calculated by formulation (Cohen, 1998) and then described in more detail by Saregar, Latifah, \& Sari (2016) as followed:

$$
\mathrm{d}=\frac{m_{A}-m_{B}}{\left[\left(s d_{A}^{2}+S d_{B}^{2}\right)\right]^{\frac{1}{2}}}
$$

in which $\mathrm{d}$ : Effect size; $\mathrm{m}_{\mathrm{A}}$ : the average value gain of the experimental class; $\mathrm{M}_{\mathrm{B}}$ : the average value of the gain control class; $\mathrm{Sd}^{2}{ }_{\mathrm{A}}$ : standard deviation of the experimental class; and $\mathrm{Sd}^{2}{ }_{\mathrm{B}}$ : standard deviation of the control class. The size. effect size criteria can be determined as follows (Saregar, Latifah, \& Sari, 2016): $\mathrm{d}<0.2$ for small category, $0.2<\mathrm{d}<0.8$ for medium category and $\mathrm{d}>0.8$ for high category

Data from the analysis of student motivation then performed the test motivation to learn the difference between the two classes that use joyful learning and conventional with effect size. This test is done with a formula by Widodo (2014) as followed:

$$
\mathrm{d}=\frac{m 2-m 1}{\delta}
$$

in which d: effect size; $m \_2$ : average value of cycle 2 (experimental group); $\mathrm{m}_{-} 1$ : average value of cycle 1 (control group); and $\delta$ : standard deviation. The criteria in Effect Size can be determined as following Widodo (2014) below: $0<\mathrm{d}<0.2$ for very low category; $0.2<\mathrm{d}<0.4$ for low category; $0.4<$ $\mathrm{d}<0.6$ for enough category; $0.6<\mathrm{d}<0.8$ for high category; and $\mathrm{d}>0.8$ for very high category.

\section{Results and Discussion}

Learning is a process conducted by individuals to obtain new behavioral changes as a whole, as a result of the individual's own experience in interaction with his environment. Joyful learning is a learning process in which there is a pattern of strong relationships between teachers and students, 
without feeling forced or pressured, so that the need to create an atmosphere of democratic and noload both teachers and students to do the learning. In joyful learning, students are required to be more active and the teacher is only a facilitator. In the application of joyful learning carried out in four stages based on Permatasari, Mulyani, \& Nurhayati (2014) including experience, interaction, communication, and reflection

The results of research on the effectiveness of the joyful learning model of high order thinking skills and student learning motivation on the material Fungi (mushroom) are implemented in class X MIA 1 and X MIA 2 in SMA Muhammadiyah 1 Pontianak. The data obtained in this study is data about the results of pretest and posttest high order thinking skills were measured at the beginning and end of the study, and the data on students' motivation. The following descriptions are presented the consecutively average value of high order thinking skills that can be seen in Table 4 and the data on the effectiveness of the learning model Joyful learning of the high order thinking skills in Table 5.

\begin{tabular}{|c|c|c|c|}
\hline Class & Pretest & Posttest & Gain value \\
\hline $\begin{array}{l}\text { Class X MIA } 2 \text { with a joyful learning } \\
\text { model }\end{array}$ & 20.37 & 54.45 & 34.07 \\
\hline Conventional learning model (X MIA 1) & 21.85 & 51.69 & 29.83 \\
\hline
\end{tabular}

Table 1: Average Value of High Order Thinking Skills. Max value $=100$, and Gain value $=$ score $($ posttest pretest)

\begin{tabular}{lcccc}
\hline Class & $\begin{array}{c}\text { Average Gain } \\
\text { Value }\end{array}$ & $\begin{array}{c}\text { Standard } \\
\text { Deviation }\end{array}$ & $\begin{array}{c}\text { Effect } \\
\text { Size }\end{array}$ & Category \\
\hline Experiment & 34.07 & 10.18381 & 0.31 & Sedang \\
Control & 29.83 & 8.68568 & & \\
\hline
\end{tabular}

Table 2: The Effect Size of High Order Thinking Skill in Both Classes

Table 1 provides information that the post-test given to both classes with the joyful learning model and the conventional learning model showed an average increase compared to the pre-test even though the scores were still in the low category. However, based on the gain value, the high order thinking skill of the experimental class with the joyful learning model is higher than the control class that uses conventional learning models with a difference in the gain value of 4.24. This is supported by the value of the effect size in Table 2 which shows that joyful learning is more effective to improve high order thinking skills in the medium category.

The application of the joyful learning model in the learning process, especially in the biology subjects in this study shows that the use of the learning model can improve the high order thinking skills of students at SMA Muhammadiyah 1 Pontianak. Assumptions test results from the data obtained indicate that the results of research on high order thinking skills through the U-Mann Whitney test obtained results with a significant number of 0.134 with a gain value of 34.07 which is higher than the use of conventional learning models 29.83 which indicates the existence of differences in high order thinking skills of students in the experimental and control classes. The effectiveness of the use of joyful learning in increasing high order thinking skills has also been proven from the calculation of the effect size of 0.31 which shows effective in the medium category.

The application of this joyful learning model students is divided into 4 groups with the heterogeneous member for discussions. Learning begins with a pretest conducted to determine the ability of beginning students. The task of the student group that is seeking information about the material fungi base on a worksheet provides learners with a different theme. With the assignment, students can dig up as much information to understand the material fungi. Students exchanged information with a friend by communicating with a friend or teacher. The information that has been obtained by students is then presented or published to classmates using the media that is pasted and then a reflection or justification of information is held by the teacher. Students can also find their 
concepts through questions given by teachers or friends so that the learning process becomes interesting and the learning atmosphere becomes fun.

Their division into learning groups will encourage the establishment of mutually supportive relationships between group members. Students who have difficulty can ask the friend of the group that is expected to enhance the students' problem-solving abilities and gain maximum learning results. And train students' thinking skills or high order thinking skills through discussion activities

In contrast to the control classes that implement conventional learning models, in this class of media that are presented with the sticking game to the experimental class used as a media for students to explain fungi materials of the results group discussion in class. Although the stages of learning to do the same, the learning atmosphere which monotonous makes students' lack of enthusiasm. So that the value of the high order thinking skills obtained is still below the experimental class with a value gain of 29.83 .

The application of high order thinking skills in SMA Muhammadiyah 1 Pontianak initially had difficulties felt by students, which in SMA Muhammadiyah 1 Pontianak use of high order thinking skills matter as an evaluation of learning has never been given. This is evident from the results of the pretest graders experimental and control with the average value of a sequence that is 20.37 and 21.85. This value shows that none of the students who complete and has reached the target value of the thoroughness of the school is 75. The results were below target at pretest is normal for students not yet accustomed to the difficult problem. On the second occasion giving questions about high order thinking skills through posttest activities, students have not been able to reach the target of maximum completeness. But the results of the application of the joyful learning model have been able to improve students' high order thinking skills by an average in the experimental and control classes respectively 54.45 and 51.69 .

Based on these findings the researcher found that by using joyful learning students can fun learn. This activity led to better interaction between students and students and teachers which may lead to better student' learning outcomes. Also, a joyful learning model encourages students to become actively work together and share ideas for solving problems and be responsible, and still be able to understand the subject matter of biology well. It fits with the approach of high order thinking (HOT), which outlines productive learning activities, especially in the socio-cognitive interaction (Widodo \& Kawarwati, 2013).

Value at the end of the study (post-test), which is still below completeness is normal because this is the first-time students in facing the problem of high order thinking skills. However, this value is quite good with the increase. This suggests that the high order thinking skills can be taught and can be trained. For high order thinking skills that students can be developed sustainably. Students are trained in high order thinking skills from the beginning will be easy to expand the capacity to think at the next school level. This is consistent with the statement (Afcariono, 2008) that the ability to think (high order thinking skills) cannot occur spontaneously due to these capabilities need to be trained. Changing a person's ability to think we need a process and exercise is not short. The factors that influence student learning outcomes including high order thinking skills can come from external factors such as the family environment and school environment, and internal factors such as physiological and psychological conditions of students (Suryabrata, 2005).

The use of two-tier multiple-choice questions in measuring students' high order thinking skills was chosen because it has several advantages. The advantages of multiple-choice questions, among others, the number of graded material that can be asked is relatively more than the material covered about in narrative form; can measure the level of high order thinking skills (analysis, evaluation, creation) which is generally difficult for the usual multiple-choice questions; scoring easy, fast, and objective; about relatively higher reliability as compared to a matter of description; can be used to measure problem-solving ability; can be used as a diagnostic tool for students' understanding of the material; can be used to detect the possible misconceptions of the students; can be used to determine the effectiveness of learning that teachers; opportunities to guess or shoot fewer answers because between 
the first-level questions with the second level questions are interrelated (Nofiana, Sajidan, \& Puguh, 2014), so it is expected to be able to measure students' high order thinking skills objectively.

The research data regarding student learning motivation is described in table 3 , namely the average value of student learning motivation, Table 4 the value of student learning motivation indicators and Table 5 results of the effect size of student learning motivation in fungi material at SMA Muhammadiyah 1 Pontianak, as follows:

\begin{tabular}{cc}
\hline Class & Average value \\
\hline $\begin{array}{c}\text { joyful learning model (X } \\
\text { MIA 2) }\end{array}$ & 82.54 \\
$\begin{array}{c}\text { Conventional learning } \\
\text { model (X MIA 1) }\end{array}$ & 75.25 \\
\hline
\end{tabular}

Table 3: The Average Value of Student' Learning Motivation

\begin{tabular}{clcc}
\hline No & \multicolumn{1}{c}{ Indicator } & $\begin{array}{c}\text { Experimental } \\
\text { Class }\end{array}$ & Control Class \\
\hline 1 & Indicator of willingness in & 77.50 & 71.17 \\
& learning & 88.33 & 78.67 \\
3 & Indicator of cooperation & 83.33 & 77.67 \\
4 & Indicator of student attention & 81.00 & 73.50 \\
\hline
\end{tabular}

Table 4: Value of Student' Learning Motivation indicators

\begin{tabular}{lcccc}
\hline \multicolumn{1}{c}{ Class } & $\begin{array}{c}\text { Average } \\
\text { score }\end{array}$ & $\begin{array}{c}\text { Standard } \\
\text { Deviation }\end{array}$ & $\begin{array}{c}\text { Effect } \\
\text { Size }\end{array}$ & Category \\
\hline Experiment & 82.54 & 8.94632 & 1.15 & Very high \\
Control & 75.25 & & & \\
\hline
\end{tabular}

Table 5: The Effect Size of Student' Learning Motivation

Based on the data in table 3, the average score of students' learning motivation in the experimental class with the joyful learning model shows a higher value than in the control class with a difference of 7.29. In table 4 the highest indicator of learning motivation in these both classes is the indicator of cooperation. Besides, table 5 shows the results of the effect size of students' learning motivation with the joyful learning model indicate values that occupy a very high category.

One of the factors that cause an increase in student motivation is the implementation approach of joyful learning, in which using the model lesson students become more comfortable in learning so that students are no longer afraid to contribute opinions during discussions and are not afraid to ask if it is not yet understood. Motivation arising on students will make the students more interested and become more active when the discussions that will be interwoven interactions between members of the group well. This good interaction will make group members help each other to understand the learning materials and students who already know can help students who don't understand (peer tutoring). According to Indrianie (2015), peer tutoring was a very helpful teacher empowering the potential of understanding the concepts and thinking skills of learners, both for students' low academic ability and high academic ability. In the learning process of a student's explanation is much more easily understood and accepted by other students because of the lack of taste and shy to ask. Peer tutoring so the explanation is very impressive and easily recorded by other students in their language which is certainly much simpler than the teacher's explanation. Besides the desire to become a tutor or help her to understand the material under discussion also makes the students are motivated to learn. Because 
based on research (S, Putu, \& W, 2013) shows that peer tutor-assisted learning can increase student motivation.

Apart from the experimental class, the control class, the students' motivation has also increased but remains under the experimental class that is the average value of 75.25. This is due to the conventional classroom learning provided less exciting or dull as a result of discussions that are tedious or less open students argue that make students feel bored. Moreover, their tasks make students feel lazy to follow the teaching of biology. So that only a few students who do the work. Though at this stage the students are taught to analyze problems and solve them with high order thinking skill that requires a lot of ideas or suggestions from other friends. Thus, students who didn't do the task, high order thinking skills which were the main objective of this study were not achieved and didn't bring up the student learning motivation expected by the teacher in each learning.

The use of sticking game media is also one of the factors in increasing student motivation, wherein with these media students are required to actively collaborate with their groups to try and find out for themselves about the answers to the results of discussions they have worked on, to create a sense of comfort and fun for students. Because according to (Kustandi \& B, 2013) learning media can help improve understanding, present data attractively and reliably, facilitate data interpretation, condense information, and arouse students' motivation and interest in learning. Also, learning with the help of learning media can give students the freedom to learn on their own according to their abilities and learning styles. Learning media can increase interest and interaction, increase the efficiency and quality of learning outcomes, foster positive student attitudes, change the teacher's role, concentrate abstract material, help overcome the limitations of the five senses, and increase student retention (Suprihatiningrum, 2013).

Although the control class also uses the same media as the experimental class, its use as a sticking game media in the experimental class is one of the aids to make the learning atmosphere in the experimental class enjoyable. Moreover, games that require accuracy and speed make students compete to quickly finish in a short time, which certainly gives the impression of excitement in the hearts of students. In contrast to the control class that is used to present in front of his classmates, the conditions are normal. In this case, students are usually done by students and do not attract the attention of students anymore.

\section{Acknowledgment}

This study can be completed properly due to the help of many people. Therefore, the authors say many thanks to Mr. Deni Hamdani, S.Pd.I. as Principal SMA Muhammadiyah 1 Pontianak and the council of teachers who have given permission and assistance in this research. And do not forget also I would like to thank the Rector of the Universitas Muhammadiyah Pontianak, Dekan FKIP, head of the program study Biology Education and lecturer researchers who have a lot of support in this research to complete.

\section{References}

Afcariono M. (2008). Penerapan Pembelajaran Berbasis Masalah Untuk Meningkatkan Kemampuan Berpikir Siswa Pada Mata Pelajaran Biologi. In Bahasa. Jurnal Pendidikan Inovatif. 3(2): $65-68$.

Hamdu G and Agustina L. 2011. Pengaruh Motivasi Belajar Siswa Terhadap Prestasi Belajar IPA Di Sekolah Dasar. In Bahasa. Jurnal Penelitian Pendidikan. 12(1): 90-96. 
Indrianie NS. (2015). Penerapan Model Tutor Sebaya pada Mata Pelajaran Bahasa Inggris Reported Speech terhadap Hasil Belajar Peserta didik MAN Kota Probolinggo. In Bahasa. Jurnal Kebijakan dan Pengembangan Pendidikan. 1(1): 126-132.

Kayali S and Yilmaz M. 2016. An Exploratory Study to Assess Analytical and Logical Thinking Skills of the Software Practitioners using a Gamification Perspective. Süleyman Demirel Üniversitesi Fen Bilimleri. 21(1): 178.

Kustandi C and Sutjipto B. 2013. Media Pembelajaran Manual dan Digital Edisi Ke Dua. In Bahasa. Bogor: Ghalia Indonesia.

Nashar. (2004). Peranan Motivasi dan Kemampuan Awal dalam Kegiatan Pembelajaran. In Bahasa. Jakarta: Delia Press.

Nofiana M, Sajidan, and Puguh. 2014. Pengembangan Instrumen Evaluasi Two-Tier Multiple Choice Question untuk Mengukur Keterampilan Berpikir Tingkat Tinggi Pada Materi Kingdom Plantae. In Bahasa. JURNAL INKUIRI. 3(II): 60-74.

Permatasari AI, Mulyani B, and Nurhayati ND. 2014. Efektivitas Penggunaan Model Pembelajaran Joyful Learning dengan Metode Pemberian Tugas terhadap Prestasi Belajar Siswa pada Materi Pokok Koloid Siswa Kelas Xi IPA SMA Negeri 1 Simo Tahun Pelajaran 2012/2013. In Bahasa. Jurnal Pendidikan Kimia. 3(1): 118-122.

Rochman S and Hartoyo Z. 2018. Analisis High Order Thinking Skills (HOTS) Taksonomi Menganalisis Permasalahan Fisika. In Bahasa. Science and Physics Education Journal (SPEJ). 1(2): 78-88.

San S, Putu R, and Widiyanti M. 2013. Pengaruh Model Pembelajaran Kontekstual Berbantuan Tutor Sebaya Terhadap Hasil Belajar Biologi Ditinjau dari Motivasi Belajar. In Bahasa. e-Journal Program Pascasarjana Universitas Pendidikan Ganesha. 3: 1-10.

Saregar A, Latifah S, and Sari M. 2016. Efektivitas Model Pembelajaran Cups: Dampak terhadap Kemampuan Berpikir Tingkat Tinggi Peserta Didik Madrasah Aliyah Mathla'ul Anwar Gisting Lampung. In Bahasa. Jurnal Ilmiah Pendidikan Fisika Al-BiRuNi. 5(2): 233-243.

Sharma K. 2013. Human Development and Southeast Asian Countries: Special Emphasis on India. Journal of Education and Health Promotion. 2(1): 45.

Sugiyono. 2015. Metode Penelitian Pendidikan dan Penelitian Kuantitatif, Kualitatif dan $R \& D$. In Bahasa. Bandung: Alfabeta.

Suprihatiningrum. 2013. Strategi Pembelajaran Teori dan Aplikasi. In Bahasa. Yogyakarta: ArRuzz Media.

Suryabrata S. 2005. Psikologi Pendidikan. In Bahasa. Bandung: Rajawali Press.

Ulya IF, Irawati R, and Maulana. 2016. Peningkatan Kemampuan Koneksi Matematis dan Motivasi Belajar Siswa Menggunakan Pendekatan Kontekstual. In Bahasa. Jurnal Pena Ilmiah. 1(1): 121-130.

Widiawati, Subandi, and Fajaroh F. 2015. Pengaruh Problem Solving Berkelompok terhadap Motivasi Belajar, Kemampuan Berpikir Kritis, dan Hasil Belajar Siswa. In Bahasa. Jurnal Ilmu Pendidikan. 21(1): 106-114.

Widodo H. 2015. Potret Pendidikan di Indonesia dan Kesiapannya dalam Menghadapi Masyarakat Ekonomi Asia (MEA). In Bahasa. Cendekia. 13(2): 293-307.

Widodo T. 2014. Metode STAD untuk Meningkatkan Motivasi dan Prestasi Belajar Pengetahuan Dasar Teknik Mesin Di SMKN 1 Purworejo. In Bahasa. E-Jurnal Pendidikan Teknik Mesin. 2(4): 16.

Widodo T and Kawarwati S. 2013. Higer Order Thinking Berbasis Pemecahan Masalah untuk Meningkatkan Hasil Belajar Berorientasi Pembentukan Karakter Siswa. In Bahasa. Cakrawala Pendidikan. (1): 161-171.

Yee M. 2015. Disparity of Learning Styles and Higher-order Thinking Skills among Technical Students. Procedia- Social and Behavioral Sciences. 143-152. 